\title{
Pyrostilpnit z ložiska Stará Vožice - Ratibořské Hory (Česká republika)
}

\author{
Pyrostilpnite from the Stará Vožice - Ratibořské Hory deposit (Czech Republic)
}

\author{
Luboš VRtišKa*, Pavel ŠKácha, ZdeněK Dolní̌̌ek a Radana Malíková \\ Mineralogicko-petrologické oddělení, Národní muzeum, Cirkusová 1740, 19300 Praha 9 - Horní Počernice; \\ *e-mail: lubos.vrtiska@nm.cz
}

VRTIŠKA L, ŠKÁCHA P, DolničEK Z, MalíkovÁ R (2020) Pyrostilpnit z ložiska Stará Vožice - Ratibořské Hory (Česká republika). Bull Mineral Petrolog 28(1): 69-73 ISSN 2570-7337

\begin{abstract}
A rare silver mineral pyrostilpnite, monoclinic $\mathrm{Ag}_{3} \mathrm{SbS}_{3}$, was found on two museum specimens from the historical Ag-Pb-Zn ore deposit Ratibořské Hory-Stará Vožice near Tábor (southern Bohemia, Czech Republic). These samples come from the mineralogical collection of the National Museum in Prague. Pyrostilpnite forms tabular crystals or groups of small striated sharp crystals of red-orange to orange color up to $2.1 \mathrm{~mm}$ in size. Pyrostilpnite occurs in close association with pyrargyrite and dolomite. Pyrostilpnite is monoclinic, space group $\mathrm{P} 2 / \mathrm{c}$ with the following unit-cell parameters refined from the PXRD studies: a 6.857(5) $\AA$, $b$ 15.851(6) $\AA, c$ 6.236(7) $\AA, \beta$ 117.2(5) ${ }^{\circ}$ and $V$ 603.1(8) $\AA^{3}$. Its empirical formula on the base of 7 apfu is $\mathrm{Ag}_{2.99} \mathrm{Sb}_{1.01} \mathrm{~S}_{2.99}$.
\end{abstract}

Key words: pyrostilpnite, powder X-ray diffraction data, unit-cell parameters, chemical composition, $\mathrm{Ag}-\mathrm{Pb}-\mathrm{Zn}$ deposit, Stará Vožice, Ratibořské Hory, Czech Republic

Obdrženo 18. 3. 2020; prijato 4. 5. 2020

\section{Úvod}

Monoklinický pyrostilpnit je relativně vzácným minerálem střibra, polymorfní modifikací hojnějšího trigonálního pyrargyritu $\mathrm{Ag}_{3} \mathrm{SbS}_{3}$. V České republice byl zjištěn na řadě lokalit, většinou však v malém množství. Pyrostilpnit zpravidla vytváří tabulkovité protažené krystaly tmavě oranžové barvy.

Historicky známé jsou výskyty na štole Antonína Paduánského v Kutné Hoře, kde byly zjištěny krystaly v dutinách křemenné žiloviny do velikosti až $4 \mathrm{~mm}$ (Vepřek 1948; Mrázek, Zeman 1981). Z Oselského pásma v Kutné Hoře ho uvádí Pažout (2005). V březohorském polymetalickém rudním revíru byl zjištěn na několika výskytech na dole Anna (KIvaňa 1886), ojediněle na dole Jarošovka (Pošepného pavilon, Ostrava), v haldovém materiálu dolu Lill (Škácha, Plášil 2002) a spolu s miargyritem na vzorku z Březových Hor pocházejícího ze sbírek Naturhistorisches Museum Wien (Škácha et al. 2018). V příbramském uran-polymetalickém revíru byl poměrně často nalézán v materiálu rudní čočky na žíle T1 (Třebsko, šachta č. 7, 1. patro) v jižní části revíru (Šrein, Řídkošil 1981; Kašpar et al. 1983, 1985). Moderně zpracován byl bohatý výskyt pyrostilpnitu na žíle H61Z (Háje) pod 6. patrem šachty č. 21 (Sejkora et al. 2007). Pyrostilpnit zde vytvářel vějírovité a paralelní srůsty protáhlých, tence tabulkovitých krystalů o délce 1 - $2 \mathrm{~mm} v$ asociaci s pyrargyritem, na puklinách kalcitu. Výjimečně tvořil až $7 \mathrm{~mm}$ mocné kůry složené $z$ rozvětvených agregátů, spolu s až $2 \mathrm{~cm}$ velkými krystaly pyrargyritu. Výskyt pyrostilpnitu z jáchymovské rudní oblasti se nepodařilo ověřit (Škácha et al. 2019).

Během příprav nových expozic Národního muzea byly při čištění a výzkumu mineralogických vzorků zjiště- ny drobné krystaly pyrostilpnitu jako další přitomný minerál na dvou historických ukázkách z revíru Stará Vožice Ratibořské Hory, evidovaných v mineralogické sbírce NM pod označením pyrargyrit.

\section{Charakteristika výskytu}

Historický rudní revír Stará Vožice - Ratibořské Hory je typickým hydrotermálním žilným Ag-Pb-Zn ložiskem s relativně jednoduchou mineralizací, reprezentovanou především křemen-karbonátovými žilami s galenitem, sfaleritem, freibergitem, pyrargyritem, vzácněji stříbrem a doprovodnými sulfidy (chalkopyrit, pyrit, arsenopyrit, akantit aj.). Sekundární minerály se zde vyskytly relativně vzácně a až na výjimky v mikroskopických ukázkách. Primární mineralizace je charakterizována $v$ práci Vrtišky et al. (2019b), výčet sekundárních minerálů pak shrnuji Vrtiška et al. (2019a). V těchto pracích je také stručně nastíněna historie tohoto rudního revíru.

\section{Metodika výzkumu}

Barevné mikrofotografie byly pořízeny pomocí mikroskopu Nikon SMZ 25 s digitální kamerou Nikon DS-Ri2 a funkce skládání obrazu za použití programu NIS Elements AR verze 4.20. Fotografie obrazu zpětně rozptýlených elektronů (BSE) byly pořizeny na elektronovém skenovacím mikroskopu Hitachi S3700-N (Národní muzeum, Praha).

Rentgenová prášková difrakční data pyrostilpnitu byla získána pomocí práškového difraktometru Bruker D8 Advance (Národní muzeum, Praha) s polovodičovým, pozičně citlivým detektorem LynxEye, za užití CuKa záření 

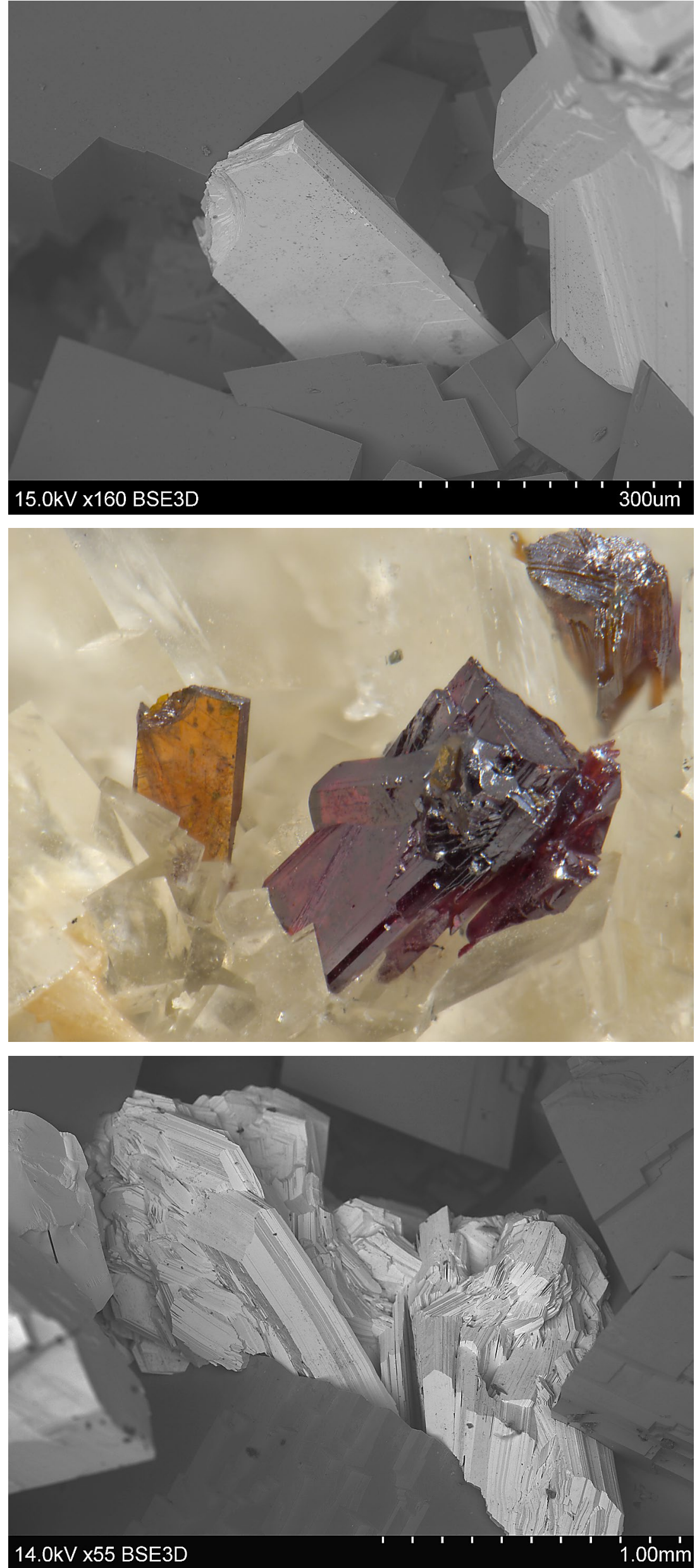

(40kV, 40 mA). Práškové preparáty byly naneseny $v$ acetonové suspenzi na nosič zhotovený z monokrystalu křemíku a následně pak byla pořízena difrakční data ve step-scanning režimu (krok $0.01^{\circ}$, načítací čas $8 \mathrm{~s} /$ krok detektoru, celkový čas experimentu cca 15 hod.). Pozice jednotlivých difrakčních maxim byly popsány profilovou funkcí Pseudo-Voigt a upřesněny profilovým fitováním v programu HighScore Plus. Mřižkové parametry byly zpřesněny metodou nejmenších čtverců pomocí programu Celref (Laugier, Bochu 2011).

Chemické složení pyrostilpnitu bylo kvantitativně studováno pomocí elektronového mikroanalyzátoru Cameca SX100 (Národní muzeum Praha, analytik Z. Dolníček) za podmínek: WD analýza, $25 \mathrm{kV}, 5 \mathrm{nA}$, průměr svazku elektronů $10 \mu \mathrm{m}$, použité standardy: chalkopyrit (SKa, $\mathrm{CuK \alpha}$ ), $\mathrm{Au}$ (AuMa), $\mathrm{Bi}_{2} \mathrm{Se}_{3}$ (BiMß), CdTe (CdL $\alpha), \quad A g$ (AgL $\alpha), \quad \mathrm{Sb}_{2} \mathrm{~S}_{3}$ (SbLa), PbS (PbMa), PbTe (TeLa), halit (CIKa), Sn (SnLa), HgTe (HgLa), pyrit (FeKa), ZnS (ZnKa), PbSe (SeL $\beta$ ), NiAs (AsL $\beta$ ), Ge (GeLa), Mn (MnKa), GaAs (GaLa). Obsahy výše uvedených prvků, které nejsou zahrnuty $\mathrm{v}$ tabulkách, byly kvantitativně analyzovány, ale zjištěné obsahy byly pod detekčním limitem (cca 0.03 - 0.07 hm. \% vyjma Pb, Se, Hg, Au a $\mathrm{Bi}, \mathrm{u}$ nichž jsou cca $0.1-0.2 \mathrm{hm}$. $\%)$. Získaná data byla korigována za použití software PAP (Pouchou, Pichoir 1985).

Obr. 1 Tabulkovitý krystal pyrostilpnitu (světlý uprostred) spolu s pyrargyritem (světlý vpravo) a krystaly dolomitu; vzorek P1N 573; šiřka záběru $0.75 \mathrm{~mm}$, BSE foto L. Váchová.

Obr. 2 Tabulkovitý krystal oranžového pyrostilpnitu spolu s temně červeným pyrargyritem a krystaly dolomitu; vzorek P1N 573; šírka záběru $1 \mathrm{~mm}$, foto L. Vrtiška.

Obr. 3 Srostlice krystalů pyrostilpnitu (světlý) spolu s krystaly dolomitu; vzorek P1N 9741; šírka záběru $2.1 \mathrm{~mm}$, BSE foto L. Váchová. 


\section{Charakteristika vzorků s pyro- stilpnitem}

Krystaly pyrostilpnitu byly zjištěny na dvou ukázkách s téměř totožným charakterem minerální asociace avšak s různou lokalizací. Vzorek P1N 573 je lokalizován jako Stará Vožice, vzorek P1N 9741 jako Ratibořské Hory. Oba vzorky se pravděpodobně dostaly do NM již před rokem 1835 a poté byly součástí tzv. „České sbírky“, kdysi samostatně vedeného souboru minerálů z nalezišt' na územ Čech. Mineralogické vzorky z těchto dvou lokalit prakticky není možné od sebe odlišit a je pravděpodobné, že historicky docházelo $k$ jejich zaměňování. Není tedy vyloučeno, že mohou pocházet ze stejného místa nálezu. Oba vzorky jsou tvořeny křemenem, na který narůstají krystaly galenitu a sfaleritu, dále mladší krystaly křemene, částečně pokryté drobnými klencovými krystaly dolomitu. Dolomitová krusta porůstá i spodní část obou vzorků. Na tyto minerály narůstaji bohaté shluky krystalů pyrargyritu a vzácného pyrostilpnitu. Pyrostilpnit tvoří na vzorku P1N 573 velmi vzácné tenké, protáhle tabulkovité krystaly oranžové barvy do velikosti 0.35 $\mathrm{mm}$ na jeho spodní straně (obr. 1 a 2). Na vzorku P1N 9741 tvoří oranžovočervené tabulkovité rýhované krystaly pyrostilpnitu srostlici o velikosti $2.1 \mathrm{~mm}$ (obr. 3 - 6).

Rentgenová prášková data pyrostilpnitu z Ratibořských Hor (tab. 1)
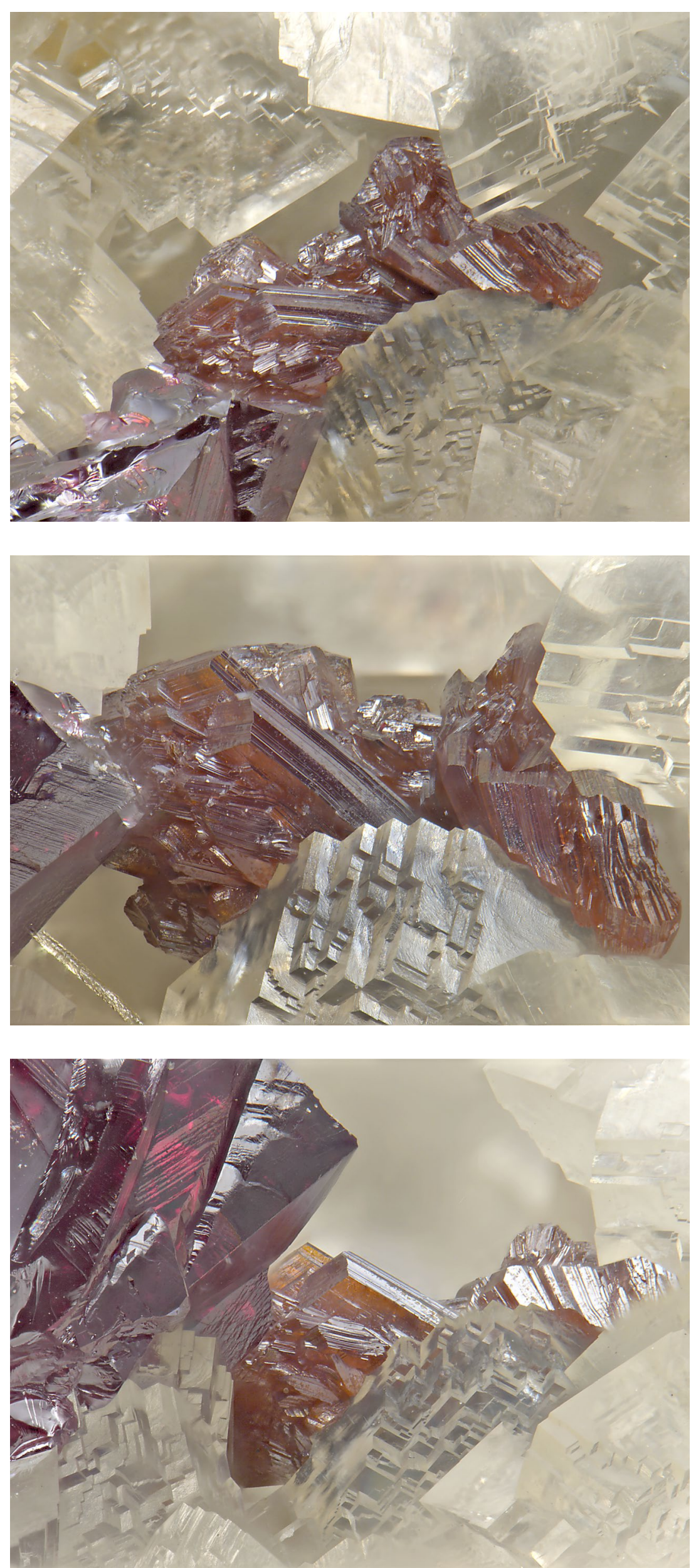

Obr. 4 Srostlice krystalů oranžovočerveného pyrostilpnitu, temně červeného pyrargyritu a krystaly dolomitu; vzorek P1N 9741; šírka záběru $3 \mathrm{~mm}$, foto L. Vrtiška.

Obr. 5 Srostlice rýhovaných tabulkovitých krystalů oranžovočerveného pyrostilpnitu spolu s temně červeným pyrargyritem a krystaly dolomitu; vzorek P1N 9741; šiřka záběru $2 \mathrm{~mm}$, foto L. Vrtiška.

Obr. 6 Oranžové rýhované krystaly pyrostilpnitu s pyrargyritem a dolomitem; vzorek P1N 9741; šiřka záběru $3 \mathrm{~mm}$, foto L. Vrtiška. 
Tabulka 1 Rentgenová prášková data pyrostilpnitu z Ratibořských Hor

\begin{tabular}{rccccccccccccccccc}
\hline$h$ & $k$ & $l$ & $d_{o b s}$ & $l_{o b s}$ & $d_{\text {calc }}$ & $h$ & $k$ & $l$ & $d_{o b s}$ & $l_{o b s}$ & $d_{c a l c}$ & $h$ & $k$ & $l$ & $d_{o b s}$ & $l_{o b s}$ & $d_{\text {calc }}$ \\
\hline 0 & 2 & 0 & 7.926 & 100 & 7.925 & 1 & 3 & 1 & 2.849 & 45 & 2.862 & -2 & 6 & 1 & 2.086 & 4 & 2.088 \\
1 & 0 & 0 & 6.102 & 8 & 6.102 & 1 & 5 & 0 & 2.815 & 21 & 2.813 & 0 & 8 & 0 & 1.9825 & 10 & 1.9813 \\
1 & 1 & 0 & 5.696 & 12 & 5.694 & 0 & 6 & 0 & 2.643 & 52 & 2.642 & 3 & 3 & 0 & 1.8985 & 8 & 1.8981 \\
-1 & 3 & 1 & 3.837 & 5 & 3.829 & 1 & 6 & 0 & 2.426 & 30 & 2.424 & -2 & 7 & 1 & 1.8862 & 11 & 1.8863 \\
-2 & 1 & 1 & 3.336 & 13 & 3.334 & -2 & 5 & 1 & 2.320 & 1 & 2.322 & -3 & 2 & 3 & 1.8027 & 1 & 1.8038 \\
-1 & 4 & 1 & 3.231 & 60 & 3.226 & -2 & 4 & 2 & 2.281 & 5 & 2.275 & -1 & 8 & 2 & 1.6731 & 3 & 1.6723 \\
-2 & 2 & 1 & 3.134 & 25 & 3.132 & 1 & 7 & 0 & 2.124 & 5 & 2.123 & -1 & 11 & 1 & 1.3935 & 1 & 1.3948 \\
2 & 0 & 0 & 3.051 & 14 & 3.051 & -2 & 5 & 2 & 2.090 & 5 & 2.090 & & & & & & \\
\hline
\end{tabular}

Tabulka 2 Parametry základní cely pyrostilpnitu pro monoklinickou prostorovou grupu $P 2_{1} / c$

\begin{tabular}{lccccc}
\hline & $a[\AA]$ & $b[\AA]$ & $c[\AA]$ & $\beta\left[^{\circ}\right]$ & $V\left[\AA^{3}\right]$ \\
\hline Ratibořské Hory (tato práce) & $6.857(5)$ & $15.851(6)$ & $6.236(7)$ & $117.2(5)$ & $603.1(8)$ \\
St. Andreasberg (Kutoglu 1968) & 6.84 & 15.84 & 6.24 & 117.15 & 601.58 \\
Třebsko (Kašpar et al. 1983) & $6.840(4)$ & $15.825(5)$ & $6.239(3)$ & $117.16(3)$ & 600.9 \\
Háje u Př́ibrami (Sejkora et al. 2007) & $6.860(1)$ & $15.854(2)$ & $6.264(1)$ & $117.18(1)$ & $606.0(2)$ \\
\hline
\end{tabular}

Tabulka 3 Chemické složení pyrostilpnitu z Ratibořských Hor (hm. \%)

\begin{tabular}{lrrrrrrrrrrr}
\hline & mean & 1 & 2 & 3 & 4 & 5 & 6 & 7 & 8 & 9 & 10 \\
\hline $\mathrm{Ag}$ & 59.06 & 58.81 & 58.98 & 60.11 & 59.64 & 59.11 & 59.15 & 57.98 & 58.58 & 58.50 & 59.78 \\
$\mathrm{Sb}$ & 22.58 & 23.45 & 22.87 & 22.06 & 21.69 & 22.74 & 23.04 & 22.89 & 23.04 & 22.20 & 21.78 \\
$\mathrm{~S}$ & 17.55 & 17.85 & 17.75 & 17.21 & 17.31 & 17.54 & 17.55 & 17.57 & 17.72 & 17.75 & 17.29 \\
\hline total & 99.19 & 100.11 & 99.60 & 99.38 & 98.64 & 99.39 & 99.74 & 98.44 & 99.34 & 98.45 & 98.85 \\
\hline $\mathrm{Ag}$ & 2.994 & 2.948 & 2.971 & 3.059 & 3.045 & 2.993 & 2.987 & 2.955 & 2.958 & 2.970 & 3.049 \\
$\mathrm{Sb}$ & 1.014 & 1.042 & 1.021 & 0.995 & 0.981 & 1.020 & 1.031 & 1.033 & 1.031 & 0.999 & 0.984 \\
\hline$\Sigma M$ & 4.007 & 3.990 & 3.992 & 4.054 & 4.027 & 4.013 & 4.018 & 3.988 & 3.989 & 3.968 & 4.033 \\
\hline $\mathrm{S}$ & 2.993 & 3.010 & 3.008 & 2.946 & 2.973 & 2.987 & 2.982 & 3.012 & 3.011 & 3.032 & 2.967 \\
\hline
\end{tabular}

mean - průměr 10 bodových analýz, báze přepočtu 7 apfu

odpovídají údajům publikovaným pro tento minerální druh i teoretickému záznamu vypočtenému z krystalové struktury (Kotuglu 1968). Zpřesněné parametry jeho základní cely jsou $v$ tabulce 2 porovnány s publikovanými daty pro pyrostilpnit.

V BSE obraze je studovaný minerál chemicky homogenní. Vedle $\mathrm{Ag}, \mathrm{Sb}$ a $\mathrm{S}$ nebyly zjištěny obsahy jiných prvků (tab. 3). Empirický vzorec pyrostilpnitu (průměr 10 bodových analýz) je při přepočtu na bázi 7 apfu možno vyjádřit jako $\mathrm{Ag}_{2.99} \mathrm{Sb}_{1.01} \mathrm{~S}_{2.99}$.

\section{Závěr}

Pyrostilpnit byl nově zjištěn jako vzácný doprovodný minerál $v$ rudách historického Ag- $\mathrm{Pb}-\mathrm{Zn}$ revíru Stará Vožice - Ratibořské Hory. Toto zjištění rozšiřuje současné znalosti o této oblasti a podává nové informace o variabilitě zdejší ušlechtilé stříbrné mineralizace. Studované vzorky jsou součástí mineralogické sbírky Národního muzea a budou vystaveny $v$ rámci nově připravované mineralogické expozice $v$ historické budově Národního muzea na Václavském náměstí v Praze.

\section{Poděkování}

Autoři děkuji Ing. Lence Váchové z Národního muzea $\checkmark$ Praze za zhotovení BSE fotografií. Předložená práce vznikla za finanční podpory Ministerstva kultury ČR v rámci institucionálního financování dlouhodobého koncepčního rozvoje výzkumné organizace Národní muzeum (00023272 - cíl DKRVO 1.II.b).

\section{Literatura}

KAŠPAR P, ŘídKoŠIL T, ŠreIn V (1983) Minerogeneze žíly T1 z Třebska u Př́brami. Acta Univ Carol Geol 1-2: 61-96

KAŠPAR P, ŘídKoŠIL T, ŠreIN V (1985) Silver-rich minerals from Třebsko near Příbram, Central Bohemia, Czechoslovakia. N Jb Miner Mh 1: 19-28

KLvañA J (1886) Nerosty království Českého. Uherské Hradiště: 1-201(heslo: Příbram)

Kutoglu A (1968) Die Struktur des Pyrostilpnits (Feuerblende) $\mathrm{Ag}_{3} \mathrm{SbS}_{3}$. N Jb Miner, Monatsh: 145-160

LAUgier J, Bochu B (2004) LMGP-suite of programs for the interpretation of X-ray experiments. ENSP/Laboratoire des Matériaux et du Génie Physique, Grenoble, France

MrázeK Z, Zeman M (1981) Pyrostilpnit z Kutné Hory. Čas Mineral Geol 26: 432

PAŽout R. (2005) Minerály stříbra v kutnohorském rudním revíru. Minerál 13(1): 3-13

Pouchou JL, PICHOIR F (1985) "PAP" ( $\varphi \rho Z)$ procedure for improved quantitative microanalysis. In: Microbeam Analysis (J. T. Armstrong, ed.). San Francisco Press, San Francisco: 104-106

SeJKora J, Litochleb J, Knižek F, ŠKácha P (2007) Charakteristika výskytu Ag-mineralizace na žile H61Z pod 6. patrem, šachta 21, př́bramský uran-polymetalický revír. Bull mineral-petrolog Odd Nár Muz 14-15: 107-113 
ŠKÁCHA P, KolitSCH U, SEJKORA J (2018) Miargyrit v asociaci s pyrostilpnitem z březohorského ložiska, Příbram (Česká republika). Bull Mineral Petrolog 26(2): 247 249

ŠKÁCHA P, PLÁšIL J (2002) Minerály březohorského rudního revíru. Bull mineral-petrolog Odd Nár Muz 10: 43-77

ŠKÁCHA P, PLÁŠIL J, HoRÁK V (2019) Jáchymov, mineralogická perla Krušnohoří. Academia: 1-688

ŠREIN V, ŘídKošIL T (1981) Genetické postavení xantokonu a pyrostilpnitu na některých lokalitách Českého masívu. In sborn: I. cyklický mineralogický semináŕ: 14-15, DT ČSVTS, Ústí nad Labem
VEPŘEK J (1948) Nové nálezy minerálů na Kutnohorsku. Výroční zpráva reálného gymnasia v Kutné Hoře 1947-1948: 1-7

VRtiŠKa L, MalíKovÁ R, DolničEK Z (2019a) Parasymplesit z haldy dolu Marie u Staré Vožice (Česká republika). Bull Mineral Petrolog 27(2): 324-330

VRtišKa L, Malíková R, DolničEk Z, Sejkora J (2019b) Pyromorfit, kintoreit a cerusit $\mathrm{z}$ historického $\mathrm{Ag}-\mathrm{Pb}-\mathrm{Zn}$ ložiska Ratibořské Hory (Česká republika). Bull Mineral Petrolog 27(2): 394-410 